\title{
Vicia vulcanorum (Fabaceae) a new species from the island of Lanzarote (Canary Islands)
}

\author{
J. GIL-GONZÁLEZ¹, M. L. GIL-GONZÁLEZ², J. B. MORALES-MATEOS ${ }^{1}$ \\ \& R. MESA-COELLO ${ }^{3}$ \\ ${ }^{1}$ Tarha Research Group, Departamento de Ciencias Históricas, Universidad de Las Palmas de Gran Canaria, \\ c. Pérez del Toro, 1, ES-35003 Las Palmas de Gran Canaria, Las Palmas, Spain \\ ${ }^{2}$ Departamento de Biología y Geología, IES Tinajo, c. Montaña Tenésar, 1, ES-35560 Tinajo, Las Palmas, Spain \\ ${ }^{3}$ C. Francisco Bermúdez, 6, ES-38500 Güímar, Santa Cruz de Tenerife, Spain
}

Author for correspondence: J. Gil-González (jgil@gmx.fr)

Editor: A. Susanna

Received 16 May 2012; Accepted 15 June 2012

\begin{abstract}
VICIA VULCANORUM (FABACEAE) A NEW SPECIES FROM THE ISLAND OF LANZAROTE (CANARY ISLANDS). - Vicia vulcanorum J. Gil \& M. L. Gil (Fabaceae), a new species of subg. Cracca (Dumort.) Peterm., sect. Cracca Dumort. is described and illustrated from the island of Lanzarote, Canary Islands, north-west of Africa. It is related to and compared with Vicia cirrhosa C. Sm. ex Webb \& Berthel. and Vicia filicaulis Webb \& Berthel., two endemic species from the western and central group of the Canary Islands, and Vicia ferreirensis Goyder, an endemic species from Porto Santo Island, Madeira Archipelago.
\end{abstract}

Key words: Africa; Cracca; eastern Canaries; Macaronesia; taxonomy.

\begin{abstract}
Resumen
VICIA VULCANORUM (FABACEAE), NUEVA ESPECIE PARA LA ISLA DE LANZAROTE (ISLAS CANARIAS). - Se describe e ilustra Vicia vulcanorum J. Gil \& M. L. Gil (Fabaceae), una nueva especie y endemismo de la isla de Lanzarote, Islas Canarias, perteneciente al subg. Cracca (Dumort.) Peterm., sect. Cracca Dumort. Se encuentra relacionada y es comparada con Vicia cirrhosa C. Sm. ex Webb \& Berthel. y Vicia filicaulis Webb \& Berthel., especies endémicas de las islas centrales y occidentales del archipiélago canario, y con Vicia ferreirensis Goyder, especie endémica de la isla de Porto Santo, en el archipiélago de Madeira.
\end{abstract}

Palabras clave: África; Canarias orientales; Cracca; Macaronesia; taxonomía.

\section{INTRODUCTION}

The genus Vicia L. (Fabaceae) is widely distributed throughout the temperate zone of the Northern Hemisphere and non-tropical South America (Leht, 2009). The number of species recognized in the genus ranges from about 140 accepted by Kupicha (1976) up to 210 used by Hanelt \& Mettin (1989).

During the field work for the "Flora Vascular de Canarias" project (www.floradecanarias.com), some interesting and previously unknown specimens of Vicia were collected by M. L. Gil in the island 


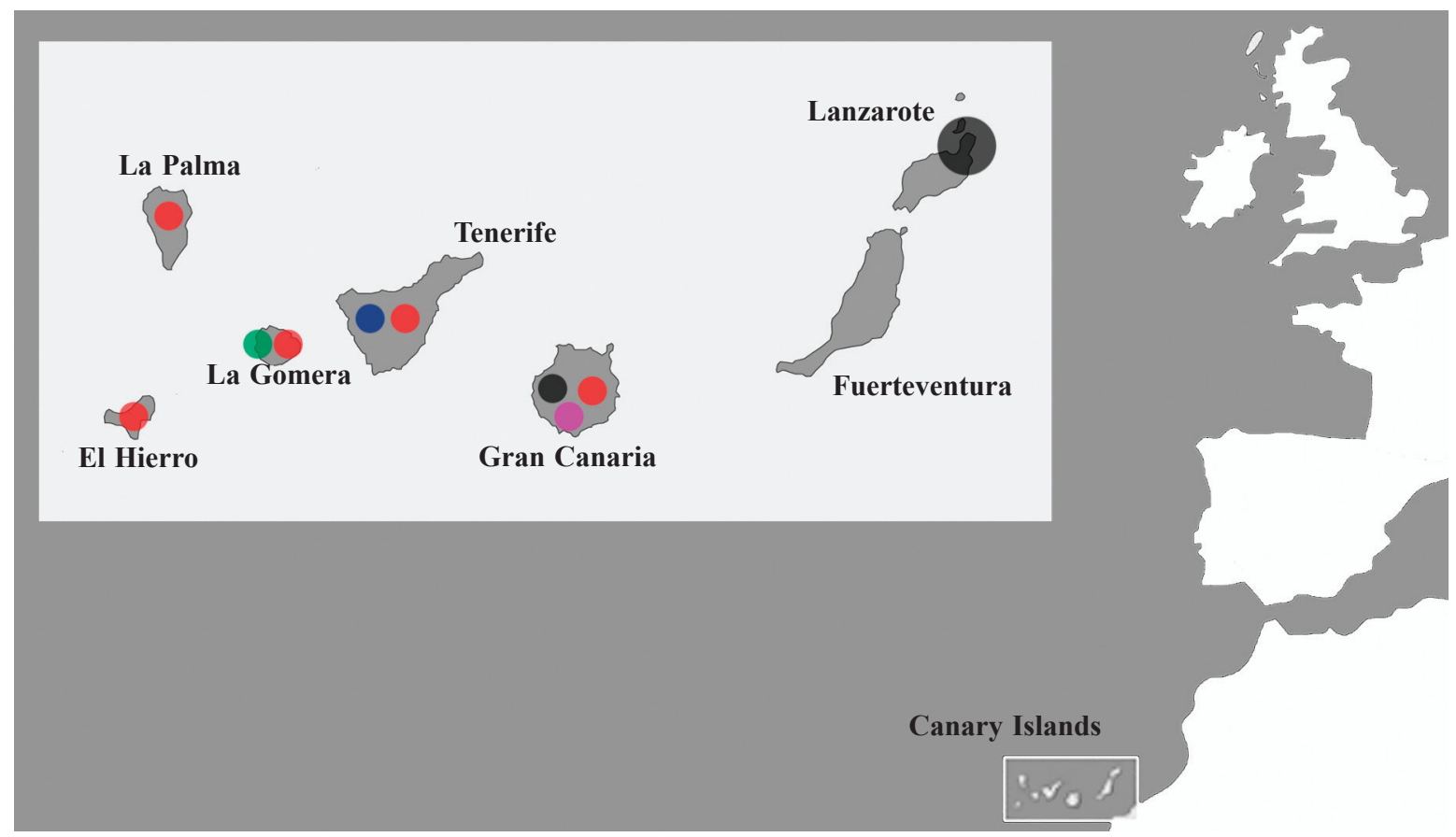

Figure 1. Map showing the location of the Canary Islands. Highlighted the area in the north of Lanzarote where Vicia vulcanorum sp. nov. occurs. The colored spots in the picture show the occurrence of all endemic Vicia species per island according to Acebes Ginovés et al. (2010) (•V. cirrhosa; $\bullet$ V. chaetocalyx; $\bullet$ V. filicaulis; $\bullet$ V. nataliae; $\bullet$ V. scandens).

of Lanzarote, Canary Islands (Fig. 1). In order to identify them, the specimens were checked in the herbaria TFC, TFMC and MADM, and against Flora of Madeira (Goyder, 1994), Flora iberica (Romero Zarco, 1999), Nouvelle Flore de l'Algérie (Quézel \& Santa, 1962), Flora of Lybia (Jafri, 1980), Flora of Egypt (Boulos, 1999), and Flora Palaestina (Zohary, 1972). Endemic Vicia from Morocco from subg. Cracca were carefully studied on the basis of their original descriptions and digitalized specimens provided by the herbaria $\mathrm{BCN}$ and MPU. As result of this work we concluded that the specimens collected in Lanzarote represent a new species.

Until now, nine species were considered to be endemic to Macaronesian Archipelagos: Vicia dennesiana H. C. Watson from the Azores, already estimated extinct (Silva et al., 2010); Vicia capreolata Lowe, Vicia costae A. Hansen, and Vicia ferreirensis Goyder from Madeira (Hansen \& Sunding, 1993; Goyder, 1994; Jardim \& Menezes de Sequeira, 2008); and Vicia chaetocalyx Webb \& Berthel., Vicia cirrhosa C. Sm. ex Webb \& Berthel., Vicia filicaulis Webb \& Berthel., Vicia nataliae U. Reifenb. \& A. Reifenb., and Vicia scandens
R. P. Murray from the Canaries (Acebes Ginovés et al., 2010). Most of the Canarian species are considered endemic to a single island and only $V$. cirrhosa is present in more than one island. None of them has ever been reported from the eastern and drier islands Fuerteventura and Lanzarote. It is rather probable that due to its short life cycle and aptitude to blend with the environment, this new species of Vicia has not been noted until now despite of the intense botanical research carried out across the island in the past decades (Duvigneaud, 1974; Kunkel, 1982; Marrero et al., 1995, ReyesBetancort, 1998). Aged local goat shepherds shown to know it well and have named it as chinipilla, an old vernacular name of Berber origin probably inherited from the pre-Hispanic inhabitants of the island (Gil et al., 2009). The shepherds' accounts also pointed out its extreme abundance in the past and the good quality of this plant to feed the goats.

Only one population of this new species has been found so far, and it has a low number of individuals. It is away from inhabited places or farming and shepherding areas, but the main threat to this plant is the massive flow of tourists and cars to Cueva de los Verdes, an important tourist centre close to the population. 
Table 1. Comparison between Vicia vulcanorum and its most closely related endemic Vicia from Macaronesian Archipelagos.

\begin{tabular}{|lcccc|}
\hline Characters & V. vulcanorum & V. ferreirensis & V. cirrhosa & V. filicaulis \\
\hline Number of leaflet pairs per leaf & $(2) 4-5(6)$ & $4-6$ & $2-4$ & $1-3(4)$ \\
Leaflet apex shape (mostly..) & mucronate & truncate-emarginate & apiculate & acuminate \\
Number of flowers in a raceme & $1-5(7)$ & $1-4(5)$ & $(1) 3-16$ & $1-3(5)$ \\
Legume length (mm) & $36-42$ & $34-45$ & $42-51$ & $39-56$ \\
Legume width (mm) & $5-6$ & $4-7$ & $3-5$ & $3-4.5$ \\
Number of seeds per pod & $(4) 5-7$ & $4-6$ & $9-12$ & $7-12$ \\
Seed length (mm) & $3.3-4.3$ & $4.5-5.4$ & $1.85-3.3$ & $2.0-3.2$ \\
Hilum length relative to the length & $1 / 6$ & $1 / 4-1 / 5$ & $1 / 8-1 / 10$ & $1 / 8-1 / 9$ \\
of the seed circumference & & & \\
\hline
\end{tabular}

\section{MATERIAL AND METHODS}

Morphological characters traditionally used in the description of Vicia species were evaluated and, in order to determine their stability, seeds gathered at the classical locus of the new species were sowed at Centro de Agrobiodiversidad de La Palma (CAP) under very different edaphoclimatic conditions. Features of gross morphology were examined under a binocular stereoscopic microscope and stylar features with a transmitted light microscope. The new species was compared with $V$. cirrhosa, $V$. filicaulis and V. ferreirensis.

\section{RESULTS}

Vicia vulcanorum J. Gil \& M. L. Gil, sp. nov. (Figs. 2 and 3).

Planta annua, glabra, vel subglabra. Caules numerosi, ramosi, angulati, prostrati l. scandentes usque ad 2.15 m. longi. Folia (2)4-5(6) juga, absque cirrho 32-49(62) mm. longa, apice cirrho simplici l. ramoso praedita. Foliola satis distantia, subglabra, alterna, elliptico-oblonga, elliptico-lanceolata vel in foliis superioribus elliptico-linearia vel linearia, apice mucronata, basi subrotundata $l$. in foliis superioribus cuneata, breviter petiolulata (ca. $0.5 \mathrm{~mm}$ ), petiolulo puberulo, 8-19(25) $\mathrm{mm}$ longa, 0.9-2.9 mm lata. Stipulae minutae, semihastatae, acutissimae. Racemi florendi folio fulcrante breviores, raro subaequilongi, 1-5(7)-flori, pedunculati, non semper aristati. Flores parvi $[10-11(13.1) \mathrm{mm}$ longi] brevissime (ca. 1-2 mm) pedicellati, subnutantes. Calyx zygomorphus; tubus campanulatus, glaber, dentibus valde inaequalibus: superioribus brevissimis; inferioribus lanceolatis, apiculatis, tubo brevioribus. Corolla glabra, angusta; vexillum albidum, pallide violaceum apparentibus, apice valde emarginatum, medio leviter constrictum, calyce triplo aut quadruplo longius. Alae vexillo subaequilongae, albidae, venis violaceis ornatae, apice pallide violaceae, carinam superantes. Stylus leviter curvatus, a lateribus compressus, apice circumcirca hirtellum. Legumen subpendulum, glabrum, 36-42 mm longum, ca. 5-6 mm. latum, reticulatum, compresum, oblongum, apice oblique truncatum, (4)5-7 spermum, ad suturas bruneo maculatum. Semina (vix matura) grisea, albido- et fusco-marmorata, punctis minutissimis viridibus irregulariter sparsis obsita, parum compressa, ovata vel oblongo-ovata, 3.3-4.3 mm longa; 2.4-3 m. lata; hilo oblongo-lineari sextam partem peripheriae seminis aequante.

Type: Spain, Lanzarote: Haría, on Malpaís de La Corona, $90 \mathrm{~m}$, on lava fields, spreading over Euphorbia balsamifera Ait., 9.04.2011, M. L. Gil 6429 (holotype: TFMC/PV).

Paratypes: Spain, Lanzarote: Haría, Malpaís de La Corona, 27.04.2011, J. Gil 6430, 6431, 6432 (TFMC/PV). La Palma: Breña Alta, Buenavista, ex horto Centro de Agrodiversidad de La Palma, 24.02.2012, M. L. Gil 913552 (BC); Breña Alta, Buenavista, ex horto Centro de Agrodiversidad de La Palma, 13.03.2012, J. Gil 6469 (TFMC/PV). 


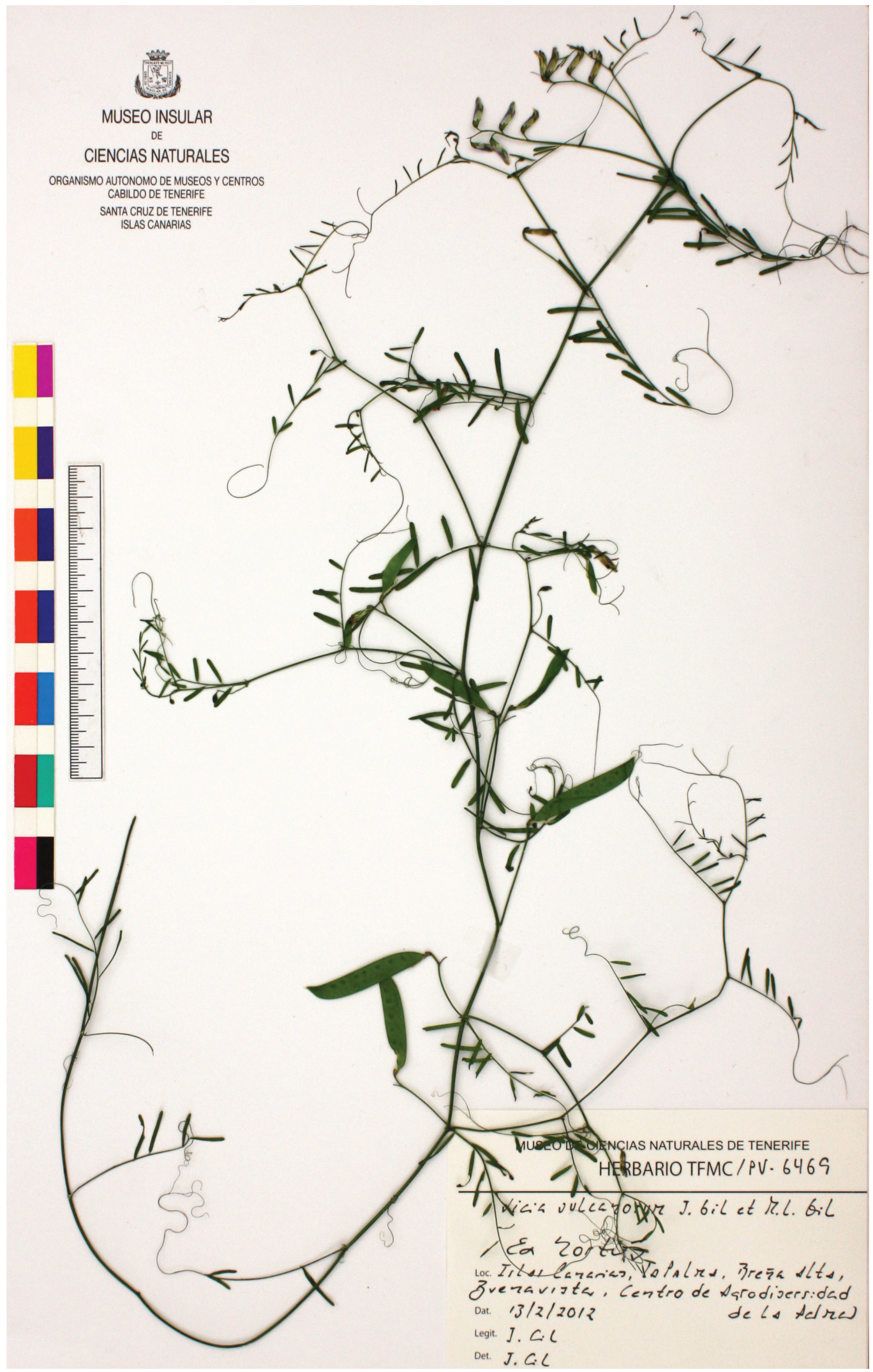

Figure 2. Habit of Vicia vulcanorum [Spain, La Palma: Breña Alta, Buenavista, ex horto Centro de Agrodiversidad de La Palma, 13.03.2012, J. Gil 6469 (TFMC/PV)]. Scale bar: $10 \mathrm{~cm}$. 

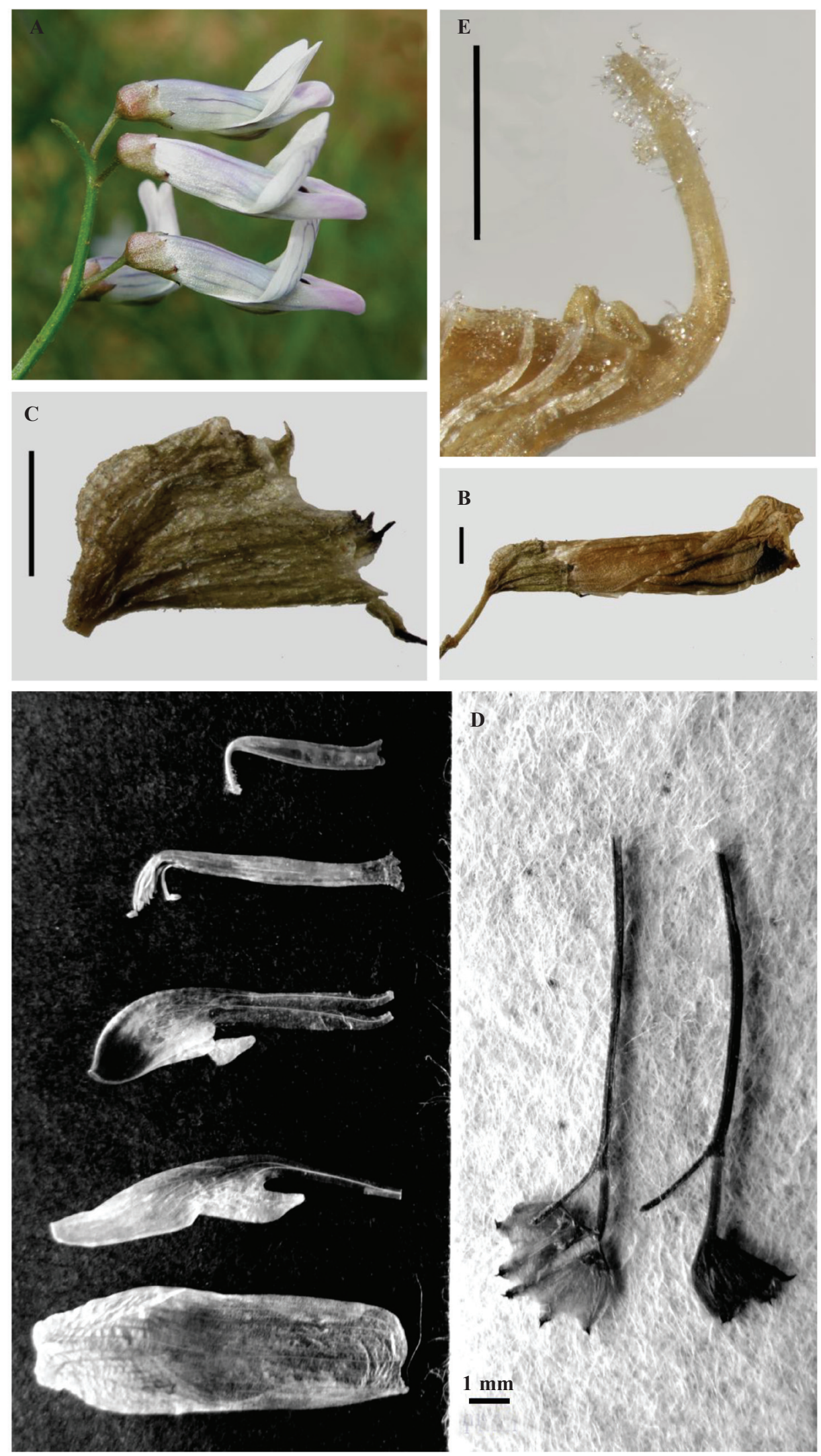

Figure 3. Floral features in Vicia vulcanorum: (A), inflorescence in the field; (B), dry flower removed from the holotype; (C), calyx; (D), detailed floral dissection on dry flower; (E), style. Scale bars: $1 \mathrm{~mm}$. 


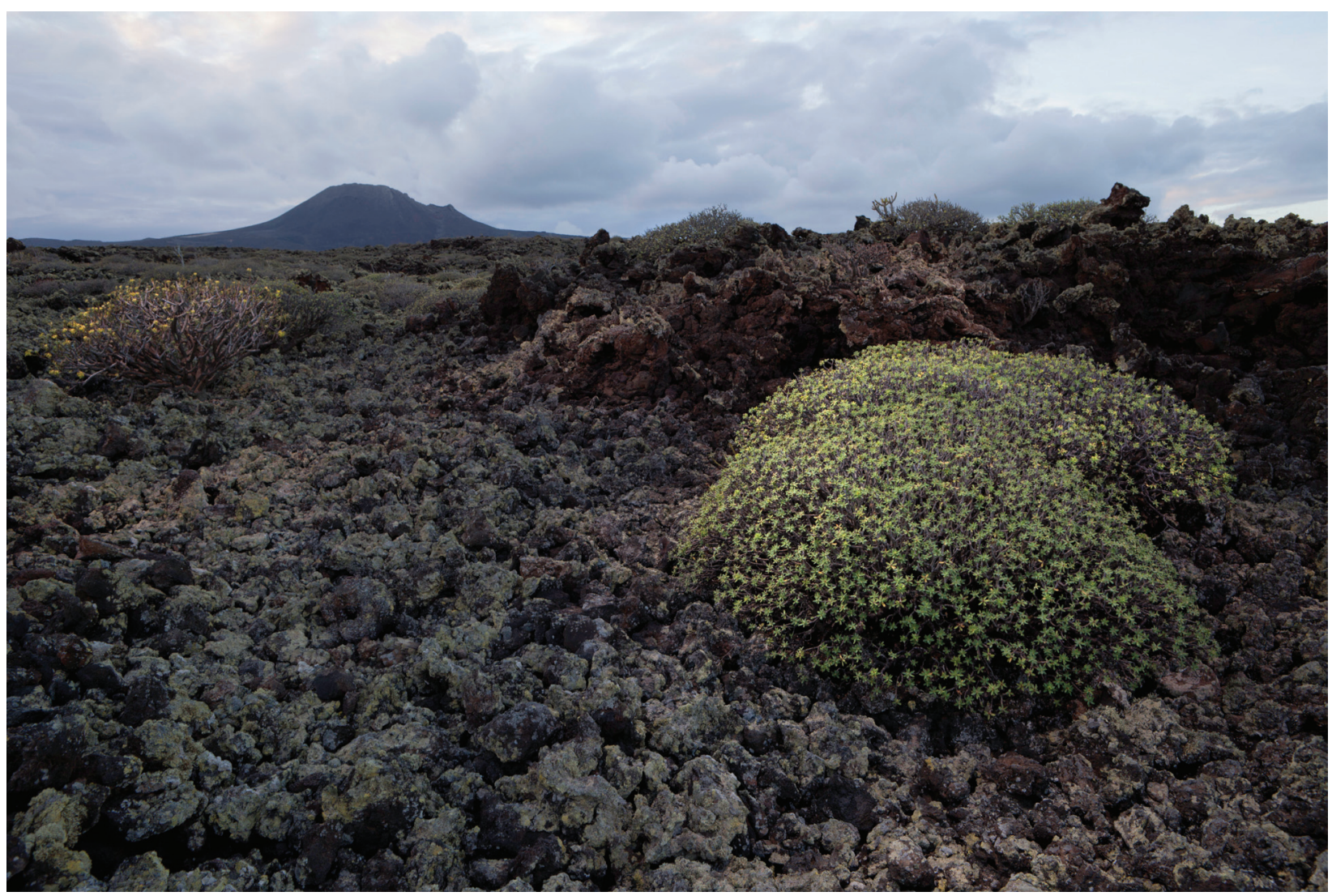

Figure 4. General view of type locality of Vicia vulcanorum. In the background, the long-extinct volcano La Corona. Euphorbia balsamifera in botton right corner (Photograph: J. Farray).

Annual herb, intricately branched, predominantly glabrous or slightly pubescent. Stems slender, numerous, $0.3-2.15 \mathrm{~m}$ or more high, sprawling or climbing, angled and grooved. Leaves subglabrous, parapinnate, 32-49(62) $\mathrm{mm}$ long (excluding the tendril), with (2)4-5(6) pairs of alternate, remote leaflets, usually with long branched (usually bi- or trifid) or simple (rare) tendrils; Leaflets 8-19(25) mm long, 0.9-2.9 mm wide, lanceolateelliptic, narrowly oblong-elliptic or linear-elliptic to linear in the upper leaves, mucronate, shortpetiolulated ( $c a .0 .5 \mathrm{~mm}$ ), petiolule puberulus. Stipules minute, semi-hastate, rare lanceolate or linear, pointed or obliquely truncate at apex, the latest deeply anthocyanin-pigmented. Racemes of inflorescences 1-5(7)-flowered, usually aristate, shorter than the leaves, rare \pm equalling the leaves, peduncles (6)15-65 mm long, sparsely puberulus. Flowers slightly pendent, 10-11(13.1) mm long; pedicels $c a$. 1-2 mm long. Calyx glabrous, slightly gibbous at base, campanulate, weakly zygomor- phic, with fine unequal teeth, the two upper almost absent, shorter than tube, broad, acute or acuminate, their points curving inwards towards each other, soon turning purple; intermediate triangular, sharply acuminate, lowest lanceolate, acuminate, about half as long the tube. Corolla glabrous, $c a$. 3-4 times as long as calyx, mostly white, violet tinged; standard 10-12.8 mm long, pandurate with the limb curving upwards, deeply emarginated with indigo veins; wings almost as long as standard, 9.8-12.1 mm long, lamina oblong, auriculate at base, claw very slender, shorter than lamina; keel shorter than wings, 8-9 mm long, lamina little shorter than claw and a dark purple blot at the apex, the latest blunt or minutely apiculate. Style curved, laterally compressed, hairy chiefly beneath the stigma with eglandular spreading hairs. Legume glabrous, reticulate, straw colored when mature with pigmented suture, flattened, 36-42 $\mathrm{mm}$ long, 5-6 mm wide, oblong, cuneate at base, obliquely truncate at apex, with (4)5-7 seeds, not compressed 
$\mathbf{A}$
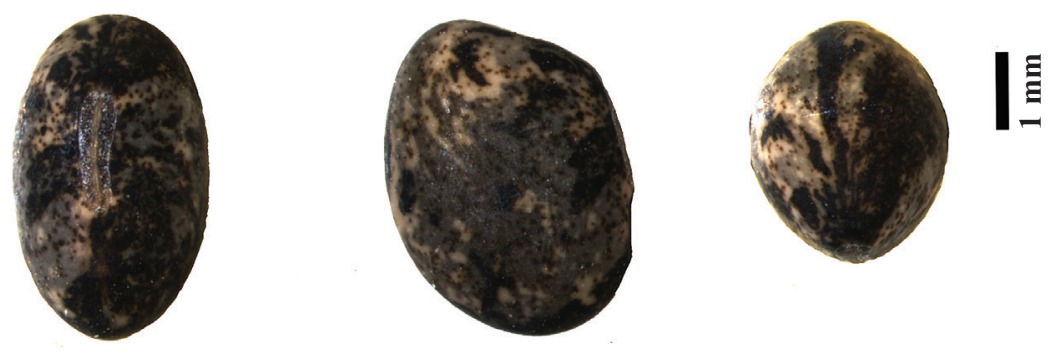

B
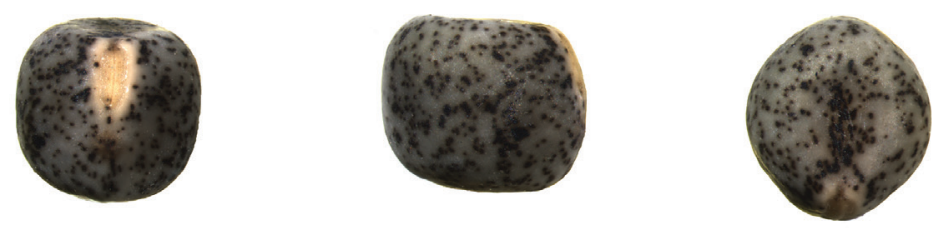

C
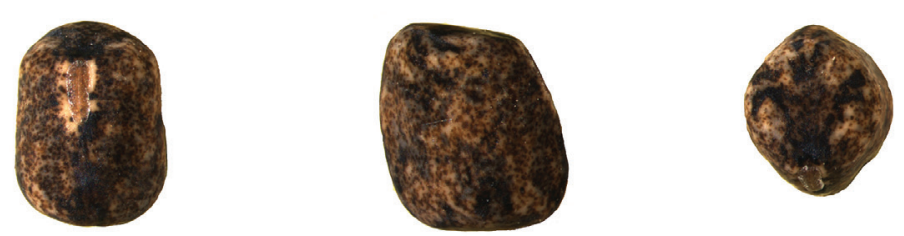

D
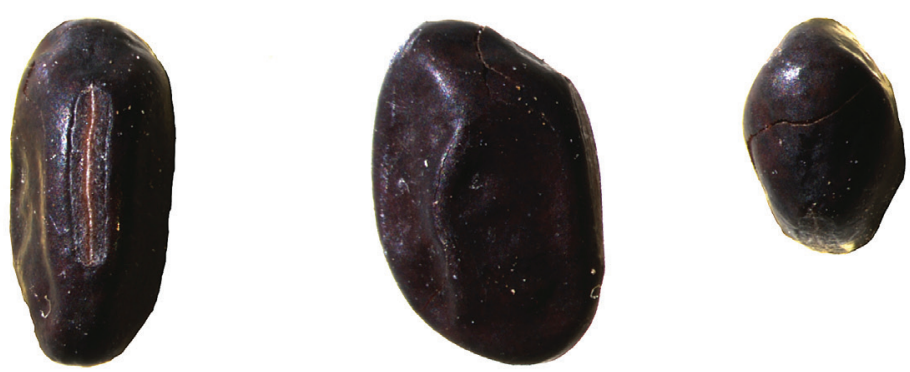

Figure 5. Ventral, lateral and zenithal views of seeds from: (A), Vicia vulcanorum [TFMC/PV-6430]; (B), Vicia filicaulis [TFMC/PV-6471]; (C), Vicia cirrhosa [TFMC/PV-2870]; and (D), Vicia ferreirensis [MADM-2523].

with each other. Seeds ovate to oblong-ovate, dull, smooth, grey, irregular black and white marble and spotted with small dark green dots, $3.3-4.3 \mathrm{~mm}$ long, 2.4-3 mm wide, $1.65-2.4 \mathrm{~mm}$ thick, hilum length $1 / 6$ of circumference.

Etymology: The new species is named Vicia vulcanorum on account of its habitat and the island where it grows, commonly known as "Isla de los Volcanes" (Insula vulcanorum).

Additional specimens examined: Vicia cirrhosa C. Sm. ex Webb \& Berthel.: Spain, Gran Canaria: Barranco Azuaje, 300 m, 22.04.1986, C. Suárez \& G. Rodríguez 31491, 31492 (TFC); Moya, Barranco de Los Dragos, frente a La Montañeta, 350 m, 
23.03.1985, C. Suárez \& G. Rodríguez 31515, 31516, 31517 (TFC). Tenerife: Adeje, Roque Bento, 19.02.2011, Mesa Coello 877479 (BC); Adeje, Tijoco Alto, 23.03.2011, J. Gil et al. 877437 (BC); Arico, Barranco de Icor, 3.03.1991, Mesa Coello 3064 (TFMC/PV); Arico, Barranco de la Magdalena, 8-10.04.2011, Mesa Coello 918152 (BC); Arico, Barranco de Tamadaya, 1400 m, 13.04.1990, Mesa Coello 2870 (TFMC/PV); Arico, Barranco de Vijigua, 400 m, 8.03.2011, Mesa Coello 913549 (BC); Güímar, La Medida, Barranco del Calvario, 24.02.1991, Mesa Coello 2911 (TFMC/PV). Vicia ferreirensis Goyder: Portugal, Madeira: Island of Porto Santo, Pico de Ana Ferreira, 04.1940, Costa 2523 (MADM); Island of Porto Santo, Pico de Ana Ferreira, 100 m, 19.03.2007, L. Medina et al. 757844 (MA). Vicia filicaulis Webb \& Berthel.: Spain, Gran Canaria: La Aldea de San Nicolás, Barranco de La Aldea, 250 m, 21.04.1990, Mesa Coello 2717 (TFMC/PV); Ayagaures, 19.05.2010, Mesa Coello 6471 (TFMC/PV); Barranco Arguineguín, 450 m, 19.05.2010, Mesa Coello 913551 (BC). Vicia nataliae U. Reifenb. \& A. Reifenb. (holotype): Spain, La Gomera: Lomo de La Culata, $350 \mathrm{~m}, \mathrm{U}$. Reifenberger \& A. Reifenberger 41356 (TFC). Vicia scandens R. P. Murray: Spain, Tenerife: Güímar, Fuga Cuatro Reales, Cabeceras del Barranco de Badajoz, 1050-1100 m, 16.05.1981, Wildpret, P. L. Pérez \& Del Arco 1440 (TFMC/PV); Güímar, Ladera de Güímar, 1000 m, 12.04.1991, Mesa Coello 3080 (TFMC/PV).

\section{DISCUSSION}

Vicia vulcanorum is endemic to Lanzarote Island, in the north-eastern part of the Canary Islands (Fig. 1), in the biogeographical region of Macaronesia. Vicia vulcanorum occurs on lava fields created by the long-extinct volcano La Corona in the north-west of the island, between 0-100 m (Fig. 4). Associated species include Asparagus arborescens Willd. ex Schult. f., Asparagus nesiotes Svent. subsp. purpuriensis Marrero Rodr. \& A. Ramos, Ceballosia fruticosa (L. f.) G. Kunkel, Euphorbia regis-jubae Webb \& Berthel., Helianthemum canariense Pers., Kleinia neriifolia Haw., Launaea arborescens Murb., Lycium intricatum Boiss. and Rubia fruticosa Aiton. It grows almost exclusively inside the structure of Euphorbia balsamifera Aiton, where it can reach up to $2 \mathrm{~m}$ or more. It can also grow sprawled over the surface of the ground but under these conditions it hardly completes its life cycle. It flowers and fruits in March-April.

\section{Taxonomic position}

Vicia vulcanorum belongs to subg. Cracca (Dumort.) Peterm., sect. Cracca Dumort., and it is characterized by having a platonychioid vexillum and the style laterally compressed and evenly hairy all round. The most similar species are: V. ferreirensis, from the island of Porto Santo (Madeira Archipelago, Portugal), which mostly has truncateemarginate leaflets and larger seeds provided with longer hylums; V. cirrhosa, from the western Canary Islands of El Hierro, La Palma, Tenerife and Gran Canaria, which has prominently zygomorphic calyces, peduncles usually longer than the subtending leaf (sometimes twice as long) and longer and thinner pods containing more and smaller seeds provided with shorter hylums; and $V$. filicaulis from Gran Canaria, which has a subregular calyx, narrower leaflets and thinner pods containing more and smaller seeds, compressed with each other, provided with shorter hylums. Table 1 summarizes the characters differentiating these four species and Fig. 5 illustrates their seed features.

\section{ACKNOWLEDGEMENTS}

Authors thank C. Chatelain, Y. Endo, D. Goyder, L. Medina, and E. Vela for numerous useful consultations and recommendations. We are especially indebted to P. and I. Schönfelder for critical revision of this manuscript. The Latin text was revised by C. Roux, J. M. Pérez Martel and M. Dorta. The work in the herbaria of University of La Laguna [TFC] and Tenerife Museum of Natural Sciences [TFMC] was made under the auspices of O. Rodríguez Delgado, R. Acebes Ginovés and L. Sánchez-Pinto. We are also indebted with R. Barone, R. Cano, N. Castro (CAP), O. Fragoso (TFMC herbarium), J. J. Gonçalves Silva (MADM herbarium), N. Ibáñez (BC herbarium), A. López (CAP), and M. Velayos (MA herbarium).

\section{REFERENCES}

Acebes Ginovés, J. R., León Arencibia, M. C., Rodríguez Navarro, M. L. et al. 2010. Pteridophyta, Spermatophyta. In: Arechavaleta, M., Rodríguez, S., Zurita, N. \& García, A. (Coords.), Lista de especies silvestres de Canarias. Hongos, plantas y animales terrestres. 2009. Gobierno de Canarias, Santa Cruz de Tenerife: 119-172. 
Boulos, L. 1999. Flora of Egypt 1. Azollaceae-Oxalidaceae. Al-Hadara Publishing, Cairo.

Duvigneaud, J. 1974. Contribution à la connaisance de la flore de Lanzarote (Canaries). Cuad. Bot. Canaria 22: 1-5.

Gil, J., Peña, M. \& Niz, R. 2009. Usos culturales de las yerbas en los campos de Lanzarote. Bases orales para la reconstrucción del conocimiento etnobotánico tradicional 1. Asociación para el Desarrollo Rural de Lanzarote, Arrecife.

Goyder, D. A. 1994. Vicia L. In: Press, J. R. \& Short, M. J. (Eds.), Flora of Madeira. The Natural History Museum, London: 162-167.

Hanelt, P. \& Mettin, D. 1989. Biosystematics of the genus Vicia L. (Leguminosae). Annual Rev. Ecol. Syst. 20: 199-223.

Hansen, A. \& Sunding, P. 1993. Flora of Macaronesia. Checklist of vascular plants. 4th revised edition. Sommerfeltia 17: 1-295.

Jafri, S. M. H. 1980. Flora of Lybia 86. Fabaceae. Al-Faateh University, Tripoli.

Jardim, R. \& Menezes de Sequeira, M. 2008. List of vascular plants (Pteridophyta and Spermatophyta). In: Borges, P. A. V., Abreu, C., Aguiar, A. M. F. et al. (Coords.), A list of the terrestrial fungi, flora and fauna of Madeira and Selvagens archipelagos. Direcção Regional do Ambiente da Madeira \& Universidade dos Açores, Funchal \& Angra do Heroísmo: 179-208.

Kunkel, G. 1982. Los Riscos de Famara (Lanzarote, Islas Canarias). Breve descripción y guía florística (Naturalia
Hispanica, 22). Instituto Nacional para la Conservación de la Naturaleza, Madrid.

Kupicha, F. K. 1976. The infrageneric structure of Vicia. Notes Roy. Bot. Gard. Edinbugh 34: 287-326.

Leht, M. 2009. Phylogenetics of Vicia (Fabaceae) based on morphological data. Feddes Repert. 120: 379-393.

Marrero, A., González-Martín, M., Betancort-Villalba, M. J., Carrasco, A. \& Perdomo, A. 1995. Adiciones y comentarios sobre la flora vascular de Lanzarote. Bot. Macaronés. 22: 91-110.

Quézel, P. \& Santa, S. 1962. Nouvelle flore de l'Algérie et des régions désertiques méridionales 1 . Editions du Centre National de la Recherche Scientifique, Paris.

Reyes-Betancort, J. A. 1998. Flora y vegetación de la isla de Lanzarote (Reserva de la Biosfera). PhD Thesis, Universidad de La Laguna, La Laguna.

Romero Zarco, C. 1999. Vicia L. In: Talavera, S., Aedo, C., Castroviejo, S., Romero Zarco, C., Sáez, L., Salgueiro, F. J. \& Velayos, M. (Eds.), Flora iberica 7(1). Real Jardín Botánico (CSIC), Madrid: 360-416.

Silva, L., Moura, M., Schaefer, H., Rumsey, F. \& Dias, E. F. 2010. List of Vascular Plants (Tracheobionta). In: Borges, P. A. V., Costa, A., Cunha, R. et al. (Eds.), A list of the terrestrial and marine biota from the Azores. Princípia, Cascais: 117-146.

Zohary, 1972. Flora Palaestina 2. Platanaceae to Umbelliferae. The Israel Academy of Sciences and Humanities, Jerusalem. 